\title{
Medi-Span Generic Product Identifier
}

National Cancer Institute

\section{Source}

National Cancer Institute. Medi-Span Generic Product Identifier. NCI Thesaurus. Code C54186.

A segmented numeric drug code assigned by Medi-Span, using a hierarchical classification scheme encompassing drug group, class, sub-class, name, name extension and dosage. Products assigned the same code should be pharmaceutically equivalent regarding active ing redients, dose form, route of administration, and strength. The same drug may be classified in multiple therapeutic classes. 